tive agents on intestinal oxygen consumption and blood flow in dogs. J Clin Invest 1975; 56: 484-90.

5 Secchi A, Wellmann R, Martin E, Schmidt H.

Dobutamine maintains intestinal villus blood flow during normotensive endotoxemia: an intravital microscopic study in the rat. J Crit Care 1997; 12: 137-41.

\section{Negative pressure pulmonary edema following thyroidectomy}

To the Editor:

A 60-yr-old female presented with a two and a half year long history of neck swelling. Initially she was diagnosed as having Grave's disease and treated with antithyroid drugs. Examination of the neck revealed a small diffuse thyroid swelling with no obvious retrosternal extension. Otorhinolaryngology (ENT) examination, electrocardiography, thoracic inlet and chest $x$-rays were normal. Flow volume loop showed variable extrathoracic obstruction. Computed tomography scan of the neck and fibreoptic bronchoscopy revealed slight tracheal narrowing. She underwent thyroidectomy and her intraoperative course was uneventful. Approximately ten minutes after extubation, the airway became obstructed. She had marked tracheal tug and intercostal indrawing. The airway obstruction was unrelieved by positive pressure ventilation using a Guedel's airway and facemask ventilation with an anesthetic breathing system. The trachea was reintubated and there was no evidence of laryngeal edema. Following intubation pink froth was noted coming out of the endotracheal tube (ETT). The patient was treated with furosemide, aminophylline, morphine and positive pressure ventilation in the intensive therapy unit (ITU). She received $i v$ dexamethasone in ITU for 48 hr. After three days of ventilation in the ITU her pulmonary edema resolved. Direct laryngoscopy and rigid bronchoscopy by an ENT surgeon revealed right vocal cord palsy and moderate tracheomalacia. As there was no evidence of airway obstruction while breathing spontaneously following rigid bronchoscopy, it was decided to extubate the trachea. She again became increasingly dyspneic with marked tracheal tug and intercostal indrawing. The trachea was reintubated and mechanical ventilation resumed. Finally, the trachea could be extubated after four days. The rest of her postoperative course was uneventful.

Tracheomalacia is an important clinical problem complicating long standing goitre. ${ }^{1,2}$ Tumour, strangulation, interrupted hanging, laryngospasm, ETT suctioning, bilateral vocal cord paralysis, aspirated for- eign body and pseudomembranous cast ${ }^{3}$ are just a few causes of pulmonary edema reported to date. To our knowledge, pulmonary edema secondary to postthyroidectomy tracheomalacia has not been described before. The mechanism involves an alteration in pulmonary microvascular pressure together with an increase in pulmonary capillary permeability. These are due to changes in Starling forces of pulmonary circulation, hemodynamic changes secondary to negative intrathoracic pressure, as well as hypoxia and a hyperadrenergic state. ${ }^{4}$ Tracheostomy or leaving the tube in situ for a few days are well recognized methods for managing tracheomalacia. ${ }^{5}$ Had extubation been unsuccessful we would have proceeded to carry out a tracheostomy as distal as possible to enable location below the involved tracheal segment. ${ }^{1}$

Manohar Lal Sharma FRCA

Neal Beckett FFARCSI

Paul Gormley MD FFARCSI

Belfast, Northern Ireland

References

1 Geelhoed GW. Tracheomalacia from compressing goiter: management after thyroidectomy. Surgery 1988; 104: $1100-8$

2 Abdel Rabim AA, Abmed ME, Hassan MA. Respiratory complications after thyroidectomy and the need for tracheostomy in patients with a large goitre. Br J Surg 1999; 86: 88-90.

3 DeSio JM, Bacon DR Complete airway obstruction caused by a pseudomembranous cast with subsequent negative pressure pulmonary edema. Anesth Analg 1993; 76: 1142-3.

4 Lang SA, Duncan PG, Shephard DA, Ha HC Pulmonary oedema associated with airway obstruction. Can J Anaesth 1990; 37: 210-8.

5 Shaha A, Alfonso A, Jaffe BM. Acute airway distress due to thyroid pathology. Surgery $1987 ; 102$ : 1068-74.

\section{Myasthénie et anesthésie pour chirurgie abdominale en urgence. Anesthesia for urgent abdominal surgery and myasthenia gravis}

Monsieur le rédacteur, Nous décrivons la prise en charge d'un patient myasthénique grade IIA (diplopie et faiblesse généralisée modérée) opéré en urgence d'une laparotomie. 


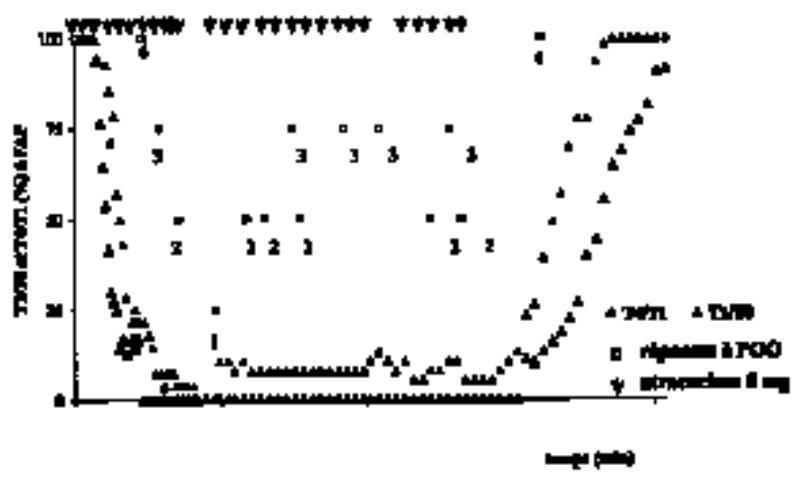

FIGURE Réponses musculaires à l'adducteur du pouce (AP) et à l'orbiculaire de l'œil (OO) après bolus itératifs d'atracurium ( ) chez un patient myasthénique.

Au quatrième jour postopératoire d'une colectomie, le patient avait développé une insuffisance respiratoire d'origine musculaire traitée par néostigmine $(0,4$ $\mathrm{mg} \cdot \mathrm{h}^{-1}$ ) et réintroduction du traitement oral (pyridostigmine + prednisone). Trois jours plus tard, il présentait une occlusion abdominale nécessitant une chirurgie.

Un monitorage neuromusculaire était installé à l'adducteur du pouce (AP) et à l'orbiculaire de l'œil $(\mathrm{OO})$. Avant l'induction, le rapport $\mathrm{T}_{4} / \mathrm{T}_{1}$ à l'AP était supérieur à 0,9 . L'anesthésie était induite par thiopental-succinylcholine $\left(1 \mathrm{mg} \cdot \mathrm{kg}^{-1}\right)$ puis maintenue par sevoflurane et sufentanil. Après récupération du bloc dépolarisant, des bolus itératifs d'atracurium $(5 \mathrm{mg})$ étaient injectés pour obtenir un bloc maximal $\left(\mathrm{T}_{1} / \mathrm{T}_{0}=5 \%\right)$. Les sensibilités à l'atracurium de l'AP et de l'OO étaient établies (Figure). La curarisation était maintenue au niveau maximal jusqu'à la fin de la chirurgie. Le patient était extubé éveillé après récupération spontanée d'un $\mathrm{T}_{4} / \mathrm{T}_{1}>0,9$.

Une instabilité du statut musculaire peut apparaître lors de l'arrêt du traitement chez un myasthénique notamment après chirurgie abdominale. Dans ce contexte, il faut recommander la triple association suivante : titration des curares - double monitorage à l'AP et à l'OO, qui permet de définir le muscle le plus sensible aux myorelaxants ${ }^{1}$ (AP pour une myasthénie sévère, $\mathrm{OO}$ pour une myasthénie responsable de diplopie uniquement) - mesure du $\mathrm{T}_{4} / \mathrm{T}_{1}$ à l'AP avant l'anesthésie, qui s'il est supérieur à 0,9 indique une sensibilité quasi normale aux curares non dépolarisants. $^{2}$
Jean-Michel Devys MD

Bertrand Debaene MD

Benoît Plaud MD

Paris, France

Poitiers, France

\section{Références}

1 Itoh $H$, Shibata K, Yoshida M, Yamamoto K.

Neuromuscular monitoring at the orbicularis oculi may overestimate the blockade in myasthenic patients.

Anesthesiology 2000; 93: 1194-7.

2 Mann R, Blobner M, Jelen-Esselborn S, Busley R, Werner $C$. Preanesthetic train-of-four fade predicts the atracurium requirement of myasthenia gravis patients.

Anesthesiology 2000; 93: 346-50.

\section{Thoracic epidural catheter placement via the caudal approach under electro- cardiographic guidance}

To the Editor:

We have developed a technique of using electrocardiography (ECG) to facilitate proper placement of a thoracic epidural catheter via the caudal route. ${ }^{1}$

After induction of general anesthesia, an $18 \mathrm{G} i v$ catheter is inserted into the caudal space to allow threading of a $20-\mathrm{G}$ epidural catheter with Johans ECG adapter assembly (Product \# TS-05430-P, epidural positioning system using Tsui test, Arrow International Inc., Reading, USA). The ECG tracings via the epidur$\mathrm{al}$ as well as the surface ECG at the desired spinal level are recorded simultaneously using a modified two channel 5 lead ECG system. The surface ECG (lead II) is first recorded by connecting the right-arm lead to a skin electrode in the patient's back in the midline, at the desired spinal level. The left-arm lead is then connected to the metal hub of the epidural catheter assembly. A satisfactory tracing (lead III) is obtained when the epidural catheter is filled with saline solution, as the catheter tip becomes a unipolar ECG electrode. The catheter is advanced from the caudal space until the tip reaches the desired level, as demonstrated by the configuration of the ECG tracing via epidural catheter matching the surface ECG tracing at the desired level.

Since this technique does not directly confirm that the catheter is in the epidural space and only provides information about the position of the catheter in relation to the heart, it is assumed that the ease with which the epidural catheter is advanced cranially indicates that it is in the epidural space and not within the subcutaneous tissues or subdural space. 